\title{
Koloniálny rozvoj: počiatky, príčiny, diskurz, prax, kontinuity a následky
}

\author{
TOMÁŠ PROFANT*
}

\author{
Colonial Development: Origins, Reasons, Discourses, Practice, \\ Continuities and Outcomes
}

\begin{abstract}
The aim of this theoretical consultation is to set the beginning of colonial development using two seemingly contradictory concepts that often appear next to each other in history - the authoritarian and the liberal governmentality. Within this framework, the paper follows the transformation from immanent to intentional development, which is the basis of authoritarianism and the shift of the term development to its social content, which is the basis of the liberal governmentality. The paper also analyzes the reasons for the origin of development during colonialism and asks the question of the continuities and discontinuities between the colonial and postcolonial era to show elements of authoritarianism and liberalism that coexist until today.
\end{abstract}

Keywords: colonialism; development; authoritarian governmentality; liberal governmentality; development cooperation

DOI: $10.14712 / 23363525.2021 .3$

\section{Úvod}

Kam datovat počiatky rozvojovej spolupráce? Kam datovat počiatky rozvoja ako ho poznáme dnes? Niektorí autori za zlomový bod prechodu do rozvojovej éry označujú inauguračný prejav prezidenta Spojených štátov, Harryho Trumana v roku 1949 [Escobar 1995: 3; Esteva 1992: 6; Rist 2008: 71; Sachs 1992: 2, pozri aj Easterly 2002: 226].

Takýto prístup nie je problematický len pre svoju empirickú nepresnost', ale najmä preto, že ostro oddeluje koloniálnu éru od rozvojovej a že v sebe môže obsahovat implicitný predpoklad, že „kolonializmus sa nezaoberal (otázkami ako morálna zodpovednost’ a humanitarizmus) a, čo je horšie, tým pádom sa nimi rozvoj nevyhnutne zaoberá“ [Kothari 2005: 50]. Podla Kothari sa treba mat na pozore pred históriami rozvoja, ktoré popierajú jeho koloniálnu genealógiu a vytvárajú hranicu medzi vykoristovaním impérií a humanitarizmom rozvoja [ibid.]. Kolonializmus totižto neobsahoval len násilie, ale mal aj svoju liberálnu stránku. Práve táto liberálna forma koloniálnej vlády je porovnatelná s dnešným rozvojovým vládnutím [Duffield - Hewitt 2009a: 9-10] a práve preto treba rozvoj vnímat aj ako prvok kolonializmu.

$\mathrm{Na}$ otázku ohladom začiatku rozvojovej éry siahajúcej do obdobia kolonializmu existujú dva vzájomne sa doplňujúce pohlady. Prvý sa týka počiatkov industrializácie, poručníctva a potreby dat smer rozmáhajúcemu sa rozvratu spoločnosti v 19. storočí [Cowen - Shenton 1996, 1999, pozri aj Williams - Young 2009]. Druhému sa venujú

\footnotetext{
* Tomáš Profant, Ph.D., Fakulta sociálnych a ekonomických vied Univerzity Komenského, Bratislava; Ústav mezinárodních vztahů, Praha. E-mail: profant@iir.cz
} 
historici kolonializmu, ktorí prvé rozvojové snahy vo vztahu medzi globálnym Severom a Juhom datujú pár desatročí pred Trumanov inauguračný prejav [Hodge 2007; Cooper 1996, 1997, 2010; Hodge - Hödl - Kopf 2014; van Beusekom - Hodgson 2000; Unger 2010; Haviden - Meredith 1993; Bendix 2016; Cooke 2003; Kothari 2005; Duffield - Hewitt 2009b; Bonneuil 2001; Coquery-Vidrovitch 1976a, 1976b; Schlauß - Schicho 2014]. Mojim cielom je oba prístupy prepojit.

Táto teoretická konzultácia vychádza z konceptualizácie rozporu medzi autoritárskym a liberálnym vládnutím počas koloniálnej a rozvojovej éry. Liberalizmus totižto nie je schopný v rámci biopolitických programov „plne kontrolovat ich ,démonické možnosti ako sa ukázalo pri nedávnych odhaleniach nútených sterilizácií v Škandinávii“ [Dean 2010: 156]. Je to práve táto konceptualizácia, ktorá umožňuje pátranie po počiatkoch rozvoja a rozvojovej spolupráce a nachádza ich v období kolonializmu. Cielom práce je teda stanovit’ počiatok rozvoja, avšak neurobit tak s časovou presnostou konkrétneho roka, či udalosti, ako to robia vyššie citovaní autori ale urobit tak pomocou teoretickej konceptualizácie autoritárskeho, či násilného a liberálneho vládnutia počas kolonializmu. Túto konceptualizáciu detailnejšie upresní aplikácia rámca liberálnej a autoritárskej guvernmentality pri diskusii sekundárnej literatúry [Dean 2010]. Z takéhoto analytického hladiska je akýkolvek presný dátum problematický a dôležitejšie je zamerat’ sa na procesy, ktoré počas kolonializmu prebiehali.

Analytické rámcovanie guvernmentality do foriem vizibility, techné a epistémé vládnutia a formovania identít [ibid.: 41-44] umožní tento argumentačný sled: Prvotný element autoritárstva ako súčast’ základného rozvojového epistemologického rámca vidno v posune od imanentného k intencionálnemu rozvoju, ako ho analyzujú Cowen a Shenton [1996, 1999]. Základom intencionálneho chápania rozvoja je poručníctvo, ktoré umožňuje autoritárstvo v rozvoji, či už koloniálnom alebo postkoloniálnom (druhá čast'). V tomto zmysle je „určitá forma ,despotizmu' prítomná v srdci liberálneho vládnutia“ hoci môže byt „relatívne benígna v podobe kultúrneho rozvoja, trénovania a výučby“ [Dean 2010: 157]. Samotný pojem rozvoj ako klúčový prvok, prostredníctvom ktorého je rozvojová doména a jej mentalita ovládaná, si prešiel vývojom počas kolonializmu, ktorý ukazuje konštantný súboj medzi ekonomickým a sociálnym chápaním tohto pojmu, teda medzi rozvojom zdrojov (inými slovami dobývaním materiálnych ziskov) a biopolitickým rozvojom ludí prostredníctvom zdravotníctva a vzdelávania. Posun k rozvoju ludí umožnil presvedčivejšiu argumentáciu ohladom dobrého (liberálneho) vládnutia nad zverenými subjektami napriek pokračovaniu násilia v tomto období (tretia čast'). Práve tu sa snúbi liberálna guvernmentalita s autoritárskou. Prečo ale vôbec došlo k posunu ku koloniálnemu rozvoju? Analýza sekundárnej literatúry ukazuje, že hoci existovali aj altruistické argumenty, cielom liberálneho vládnutia rovnako ako toho autoritárskeho ostali materiálne zisky z kolónií. Hlavnou snahou bolo upokojit búriacich sa kolonizovaných a zmeny v koloniálnej politike vo všeobecnosti vychádzali z ekonomických potrieb v metropolách (štvrtá čast'). Existujúca literatúra ukazuje koexistenciu autoritárskeho a liberálneho vládnutia v rámci nesúrodej reality reálnych koloniálnych rozvojových projektov, ktoré sa často končili neúspechmi (piata čast'). Práve analýza tejto praxe umožňuje sa zamerat’ na koloniálne kontinuity a diskontinuity (šiesta a siedma čast'). Tu sa ukážu zmeny v otázke formovania identít. Hoci sú v rozvojovej spolupráci zrejmé odlišnosti oproti koloniálnemu rozvoju, konceptualizácia liberálneho a autoritárskeho vládnutia počas kolonializmu nám 
umožňuje ukázat podobnosti medzi tým, ako sa vykonával rozvoj vtedy a ako sa vykonáva dnes. Záver prináša zamyslenie nad následkami koloniálneho rozvoja a zodpovedanie otázky položenej v úvode.

\section{Imanentný a intencionálny rozvoj v 19. storočí}

Na otázku, kedy sa začínajú dejiny rozvoja, je nutné si najprv zodpovedat’ otázku, čo to rozvoj je. Až jasná odpoved’ na ňu nám umožňuje určit jeho začiatok. Cowen a Shenton [1996, 1999] vytvárajú základné odlíšenie rozvoja ako imanentného, objektívneho procesu, ktorý sa jednoducho deje od rozvoja ako intencionálnej praxe v podobe napríklad štátnych politík [Cowen - Shenton 1999: 26]. V gramatickom ponímaní ide o posun od netranzitívneho slovesa rozvíjat’ sa k tranzitívnemu rozvíjat niečo [Arndt 1981: 460].

Avšak kým Arndt nachádza počiatok pojmu rozvoj v tranzitívnom zmysle v Austrálii 30. rokov 19. storočia a v Kanade o dekádu neskôr [ibid.: 461], Cowen a Shenton pôvod myšlienky intencionálneho rozvoja nachádzajú v princípe poručníctva v 19. storočí vo Francúzsku a Vel'kej Británii.

Potreba intencionálneho rozvoja vznikla s prechodom na priemyselný kapitalizmus v západnej Európe. Industrializácia mala za následok radikálnu transformáciu spoločnosti, zbedačenie vel'kej časti obyvatel'stva, mizériu, vysokú nezamestnanost' a deštrukciu sociálnych vztahov. 30. a 40. roky 19. storočia sú základným kontextom vzniku rozvoja ako intencionálnej snahy riadit’ rozvoj ako imanentný proces.

Zatial' čo niektorí autori ako Sismondi argumentovali proti industrializácii a v prospech obnovy sveta malých nezávislých pol’nohospodárov a remeselníkov a d’alší sa utiekali do d’alekej budúcnosti, Saint-Simonisti píšuci na konci 20. rokov 19. storočia industrializáciu obhajovali. Aj oni si však museli zodpovedat' Hobbesovu otázku, ako dosiahnut sociálny a politický poriadok. U Saint-Simonistov sa tak rodí poručníctvo ako základný prvok intencionálneho rozvoja. Kritizovali doktrínu laissez-faire a egoizmus. Cielom Saint-Simonistov sa stalo „vnútit’ konštruktívny poriadok niečomu, čo sa im zdalo ako industriálny chaos súčasnosti“ [Cowen - Shenton 1999: 24-25, pozri aj Kelemen 2009: 199]. Industrializácia bola $\mathrm{v}$ poriadku, len mala byt riadená rozumom a súcitom. Tým došlo $\mathrm{k}$ zmene v pojmu rozvoj z označovania priebehu histórie na označovanie ciela tejto histórie. Rozvoj sa stal „prostriedkom, ktorým mala byt’ epocha súčasnosti transformovaná do inej epochy prostredníctvom aktívnych cielov tých, ktorým bola zverená budúcnost’ spoločnosti“ [ibid.: 25].

Poručníkmi sa však mohli stat iba tí, ktorí mali schopnost' využit pôdu, prácu a kapitál v prospech spoločnosti. Kapitál mal byt zverený do rúk bankárov ako prostredníkov medzi pracujúcimi potrebujúcimi nástroje a majitelmi týchto nástrojov. Avšak bankári nemali podliehat' egoizmu, ale mala im byt’ vysvetlená ich funkcia poručníkov spoločnosti. "Jednoducho povedané, bankári mali byt' moralizovaní" [Cowen - Shenton 1996: 27]. Tu sa objavuje prepojenie elementu autoritárstva v podobe poručníctva s elementom etiky, ktorá je základom dobrého, liberálneho vládnutia. Liberálna a autoritárska guvernmentalita sa tak stáva jednotnou rozvojovou guvernmentalitou ešte v 19. storočí.

Saint-Simonistov doplnil August Comte svojou predstavou pozitivstickej vedy, ktorá mala odhalit’ zákonitosti spoločnosti a tým prispiet’ k spojeniu poriadku a pokroku [ibid.: 31]. V Británii to bol paradoxne teoretik slobody, John Stuart Mill, ktorý, vychádzajúc 
z Comtea, prišiel s intencionálnym rozvojom. Odlíšil prirodzený stav od prechodného. $\mathrm{V}$ prirodzenom mali materiálne záujmy spoločnosti zaistovat tí najschopnejší z hladiska spravovania spoločnosti. Pre posun od chaosu prechodného stavu do prirodzeného stavu - teda pre uloženie správy spoločnosti do rúk najkompetentnejších - bol potrebný intencionálny rozvoj, ktorý Mill nazval sociálnym strojom. Nový sociálny stroj mal byt vytvorený prostredníctvom rozšírenia vzdelania - „rozvinutia ludských mysli“ [ibid.: 39]. Vzdelávanie ako základná súčast̉ liberálnej guvernmentality malo prekonat spoločenské zvyklosti a dat' l’ud’om možnost' sa rozhodnút a tak naplnit’ svoju slobodu.

Pre Milla bola sloboda dôležitá. Jeho prístup však obsahoval základný problém, pre ktorý sa mu nepodarilo uniknút poručníctvu, ktorý sa následne prejavil v autoritárskej guvernmentalite legitimizujúcej despociu [Dean 2010: 157]. Pod vzdelávaním mal na mysli témy ako volebnú, či pozemkovú reformu, kontrolu pôrodnosti, rodovú rovnost', či práva pracujúcich. Išlo teda o vel'mi konkrétne hodnoty, ktoré mali zaistit posun do prirodzeného stavu a ktoré mali prekonat spoločenské zvyky nehodné rozvoja. Tu bol klúčový logický nedostatok jeho predstavy - význam slobody bol prítomný na konci rozvoja, počas jeho priebehu i na začiatku. Ludia sa pre vzdelávanie nemohli slobodne rozhodnút', pretože boli zviazaní svojimi zvykmi. Potrebovali teda poručníka, ktorý by rozhodol o tom, že sa majú vzdelávat za nich. Samotné vzdelávanie sa malo diat’ v podmienkach slobody, avšak jeho obsah bol stanovený vopred. A končeným cielom bola schopnost’ vykonávat slobodu, k nej sa ale malo dospiet’ prostredníctvom poručníckeho vzdelávania. Dosiahnutie rozvoja, teda vzdelania v zmysle volby predpokladalo bud' schopnost’ volit’ na začiatku celého procesu alebo poručníka, ktorý rozhodne o tom, čo možno považovat za skutočnú vol'bu. Nasledovanie tradičných zvyklostí takou vol'bou zjavne nebolo. V tomto bode Mill neuniká poručníctvu vykonávanému prostredníctvom vzdelávania a akceptuje neliberálnu prax v rámci liberálnej politickej racionality [ibid.: 158].

Mill svoju predstavu poručníctva potom rozvíjal vo vzṫahu k Indii. Tu vidno základný rozpor medzi univerzalizmom liberálnej politickej teórie na jednej strane a mocenskou nerovnostou a autoritárstvom vo vztahu ku kolóniám na strane druhej. Kým Kant legitimizoval rasový útlak predpokladajúc, že ako jedna $\mathrm{z}$ foriem spoločenských antagonizmov povedie pôsobenie prozretel'nosti $\mathrm{k}$ dosiahnutiu úplného rozvinutia ludských schopností [McCarthy 2009: 42-67, 171], Mill argumentoval v prospech kolonializmu kvôli neschopnosti „barbarov“ dosiahnut slobodu pre ich necivilizovanost' a zviazanost' zvykmi. Legitimácia násilia počas kolonializmu teda spočívala v temporalizácii univerzalizmu, ktorý mal byt dosiahnutý v budúcnosti, pretože zatial si ešte nerozvinutí „barbari“ nie sú schopní vládnut'. Koloniálny rozvoj ako súčast’ autoritárskej guvernmentality je reálnym naplňovaním (budúceho) univerzalizmu liberálnej morálky [ibid.: 171-177]. Vláda by podla neho mala mysliet’ na „najväčšie dobro svojich subjektov,“ pretože „V mnohých častiach sveta ludia pre seba nedokážu urobit nič“ [in Sheldon 2009: 55]. Pre dobro koloniálnych subjektov však bolo v poriadku využit despociu. „Tá je legitímnym spôsobom vládnutia pri zaobchádzaní s barbarmi, pokial' je cielom ich zlepšenie“ [Mill in Sheldon 2009: 81, pozri aj McCarthy 2009, pre postoj Milla k Morant Bay Rebellion na Jamajke pozri Merefield 2009].

Základným problémom imanentného rozvoja kapitalizmu bolo „prebytočné obyvatel'stvo" [Cowen - Shenton 1996: 252], ako nezamestnaných nazval Marx. Riešenie problému prebytočného obyvatel'stva tkvelo $\mathrm{v}$ intencionálnom rozvoji. Bolo potrebné toto 
obyvatelstvo nejak usmernit či už nenásilným motivovaním alebo prostredníctvom násilia. Cowen a Shenton používajú tri príklady takéhoto intencionálneho rozvoja - Viktóriu v Austrálii, Quebec v Kanade a Anglicko. Prvé dva prípady sú si podobné skúsenostou masovej nezamestnanosti a hrozbou masovej migrácie z Viktórie po roku 1856 a reálnou migráciou z Quebecu do Spojených štátov v druhej polovici 40. rokov 19. storočia. Odlišnost̉ medzi nimi tkvie v politikách intencionálneho rozvoja. Kým vláda vo Viktórii sa vydala cestou industrializácie, quebecká vláda usilovala o desatročie skôr o polnohospodársky rozvoj. Obe vlády sa však snažili zabránit strate produktívnej sily a umožnit tak pokračovanie „imanentného“ procesu kapitalistického rozvoja [ibid.: 174]. Intencionálny rozvoj teda bol reakciou na dopady imanentného rozvoja a ako jeho korekcia sledoval ciel,' „aby boli produktívne sily dostupné pre kapitál“ [ibid.: 175].

Cowen a Shenton dávajú prípad Viktórie do kontrastu s Britskou Kolumbiou, ktorej vláda sa po podobnom vytriezvení zo zlatej horúčky nevydala cestou udržania nezamestnaného obyvatel'stva na svojom území a dôsledkom bola emigrácia do Spojených štátov a finančné problémy $\mathrm{v}$ rozpočte.

Anglický príklad je odlišný v tom, že paliatívny rozvoj uzákonený Zákonom o rozvoji (Development Act) v roku 1909 mal bojovat proti migrácii z vidieka do miest a tým proti chudobe a nezamestnanosti $\mathrm{v}$ anglických mestách. Cielom rurálnej kolonizácie tak bolo zabránit úpadku v mestách i na vidieku [ibid.: 260]. Klúčové pritom bolo, že podporované polnohospodárske aktivity nemali „narúšat komoditné a finančné trhy a ohrozovat rentiérov a záujmy biznisu" [ibid.: 285]. Intencionálny rozvoj tak reagoval na dôsledky kapitalizmu. Z Európy sa intencionálny rozvoj presunul do kolónií, kde sa stal súčastou autoritárskej koloniálnej guvernmentality. Ako ukazuje nasledujúca čast', postupom času bol ekonomický význam pojmu rozvoj doplnený o jeho sociálny zmysel, čím vytvoril základ pre biopolitiku spájajúcu prvky liberálnej a autoritárskej guvernmentality.

\section{Pojem rozvoj počas kolonializmu}

Rozvoju ako nástroju na legitimizáciu kolonializmu [Hunter 2014: 102] predchádzali staršie argumenty, ktoré ospravedlňovali koloniálne vládnutie ako súčast formovania identít Seba a Druhého v rámci koloniálnej guvernmentality. Vo všeobecnosti však platí, že zodpovednost za barbarov a divochov, ktorú v koloniálnom diskurze na seba Európania prevzali bola chápaná „v zmysle civilizovania a obracania na krestanskú vieru a nie v zmysle zvyšovania životnej úrovne“ [Ziai 2016: 71]. Kedy teda možno začat hovorit o rozvoji?

Samotný pojem rozvoj bol súčastou koloniálneho diskurzu, ktorý tvoril základ koloniálnej guvernmentality od počiatku kolonializmu [Koponen 2014: 38; Doufour 2014: 322, 326]. Avšak počas kolonializmu bol rozvoj iba jedným z mnohých pojmov a viac používaný na definovanie konceptu civilizácie a civilizovania, podobne ako termíny pokrok, či progres [Doufour 2014: 328]. Doufour [ibid.: 330] poukazuje na spoločný výskyt pojmov rozvoj a civilizácia v dvadsiatych a tridsiatych rokoch 20 . storočia vo francúzskom diskurze a termín rozvoj sa stáva dominantným až po tomto prechodnom období [pozri aj Cooper Packard 1997: 7; Latouche 1988: 45].

Čo však znamená rozvoj konkrétne a kedy možno hovorit o rozvoji tak, ako ho mnohí chápu dnes v zmysle ,intencionálnej intervencie do spoločných záležitostí podla všeobecných (ak nie univerzálnych) štandardov zlepšenia“ [Hodge - Hödl 2014: 3]? 
Prvá snaha v tomto ohlade sa objavila v správe Královskej komisie pre Západnú Indiu (Karibik) v roku 1896, ktorá sa venovala príčinám krízy cukrového priemyslu. Správa trvala na morálnej povinnosti britskej imperiálnej vlády zvýšit blahobyt černošskej populácie na ostrovoch [Hodge 2007: 59]. Okrem budovania ciest a zlepšenia špedičných služieb $\mathrm{v}$ prospech ulahčenia miestneho a koloniálneho obchodu mala Britská koruna predat’ menšie pozemky lud’om, ktorí neboli schopní nájst' si zamestnanie v cukrovom priemysle. Tým správa nadviazala na biopolitickú otázku riešenia zmieneného problému nadbytočného obyvatel'stva.

Zhruba od druhej polovice nultých rokov 20. storočia silnela citlivost' k sociálnym otázkam v Bombaji [Aspengren 2009: 49]. Došlo k posunu k sociálnemu slovníku a implementácii legislatívy týkajúcej sa sociálnych podmienok, bývania, hygieny a povinného základného vzdelávania [ibid.: 45]. Sémanticky došlo k nárastu dôležitosti pojmu rozvoj dve dekády predtým.

Jeho francúzsku verziu (mise en valeur), spopularizoval od 80. rokov 19. storočia budúci premiér Jules Ferry. Tento pojem bol základom francúzskej civilizačnej misie a znamenal rozvíjanie prírodných a ludských zdrojov v kolóniách v zmysle ekonomického rozvoja, prístupu k novým zdrojom surovín a zaistovania si odbytíšt pre francúzske výrobky [Hodge 2007: 42; Hodge - Hödl 2014: 5]. Od roku 1895 bol súčastou tzv. „konštruktívneho vykoristovania“, ktoré už neznamenalo len expanziu a plundrovanie, ale systematický rozvoj kolónií [Hodge 2007: 7]. Ku konštruktívnemu vykoristovaniu patrila výstavba železníc a zlepšovanie tropickej hygieny za účelom zvyšovania objemu obchodu [Hodge - Hödl 2014: 6, 43]. Ferry zároveň veril, že úlohou „vyšších rás“ bolo zdielat výhody vedy a pokroku s „nižšími rasami“ a takto šírit civilizáciu.

Británia na tom bola podobne. Britský minister pre kolónie, Joseph Chamberlaine v 90. rokoch 19. storočia podporoval tzv. „konštruktívny imperializmus“ [Hodge 2007: 22; Koponen 2014: 6] a efektívny rozvoj imperiálnych majetkov najmä prostredníctvom budovania železníc. Ciel'om bolo zaistit’ si bohatstvo v dosial' neprebádaných oblastiach. Chamberlain argumentoval, aby bolo koloniálne územie britskej koruny rozvíjané „v prospech ludí, ktorí na ňom žijú, ako aj v prospech širšej populácie žijúcej mimo tohto územia“ [in Hodge 2007: 8].

Termín rozvoj na prelome 19. a 20. storočia znamenal "tažbu prírodných zdrojov“ [Alcalde 1987: 3], či jednoducho „rozvoj zdrojov“ [Koponen 2014: 39], pretože miestni boli považovaní za neschopných tieto zdroje rozvíjat. V neskorom kolonializme po Prvej svetovej vojne bol tento pojem vo Francúzsku používaný v súvislosti s rozvojom polnohospodárstva alebo obchodu, ekonomického rozvoja nerozvinutých krajín, či rozvoja francúzskeho Sudánu, Afrického impéria alebo západnej Afriky [Dufour 2014: 326].

$S$ posunom v tomto období prišiel Pakt Spoločnosti národov. Táto bola založená v roku 1920 na Wilsonov návrh (hoci odmietnutá americkým Kongresom). Články 22 a 23 zverovali „rozvinutým“ národom poručníctvo nad „menej rozvinutými“ oblastami a zaväzovali ich starat' sa o „blaho a rozvoj domorodého obyvatel'stva, “ títo členovia mali zároveň zaistit” „ludské podmienky pre pracujúcich na celom svete“ [Alcalde 1987: 12].

Koloniálna guvernmentalita teda postupne začala inkorporovat’ prvky liberálneho biopolitického vládnutia, ktoré koexistovali vedla snahy civilizovat’ a prinášat pravú vieru. Rozvoj zdrojov sa začínal rozširovat’ o rozvoj obyvatel'stva.

$\mathrm{V}$ dvadsiatych rokoch došlo $\mathrm{k}$ dalšiemu posunu $\mathrm{k}$ systematickejším formám ekonomického vykoristovania ako aj k reforme koloniálnej vlády [Schicho 2014a: 222]. Koloniálna 
politika v tomto období už nemala slúžit iba záujmom malého množstva ludí v metropole [Schicho 2014b: 53]. Nový spôsob vlády bol reakciou na ekonomické a politické straty spôsobené Prvou svetovou vojnou, vedomím závislosti na zdrojoch v kolóniách vrátane vojakov a potrebou majitelov kapitálu mat $k$ dispozícii lepšiu infraštruktúru a disciplinovanejšiu pracovnú silu. Rozvoj sa tak postupne stával súčastou autoritárskej koloniálnej guvernmentality.

Klúčové v tomto prípade boli texty francúzskeho ministra kolónií Alberta Sarrauta Rozvoj francúzskych kolónií [1923] - a sira Fredericka Lugarda - Duálny mandát v britskej tropickej Afrike [1922]. Duálny mandát spočíval v rozvíjaní zdrojov nielen v prospech civilizácie, teda priemyselného Západu, ale aj v snahe pomôct̉ miestnemu obyvatelstvu v podobe vzdelávania, ale s uchovaním ich vlastných zvykov a ich vlastnej správy. Malo íst o tzv. nepriamu koloniálnu vládu. Podobne tak Sarraut argumentoval v prospech investícií nielen do železníc alebo polnohospodárstva, ale aj zdravia, sociálnych a morálnych záležitostí [Cooper 1997: 65; Dufour 2014: 329].

Kým Sarrautov návrh štátneho programu budovania infraštruktúry v roku 1921 vzhladom na nedostatok financií vôbec neprešiel [Schicho 2014b: 54], britský Zákon o koloniálnom rozvoji (Colonial Development Act) z roku 1929 ešte stále nasledoval politiku, ktorej úlohou bolo podporit britskú ekonomiku [Hodge - Hödl 2014: 12, pozri aj Abbott 1971]. Koloniálny rozvoj bol francúzskou aj britskou vládou odmietnutý nielen z dôvodu potreby využit zdroje $z$ kolónií pre metropolu a nie naopak, čím by išli proti vtedy ešte platnej doktríne koloniálnej finančnej sebestačnosti [Hodge - Hödl 2014: 11; Schicho 2014b: 56], ale aj zo strachu, že občania kolónií budú požadovat svoje občianske práva vzhladom na ich zapojenie do Prvej svetovej vojny [Cooper 2010: 9].

Sarrautov prístup zakrýva aspekty vykoristovania tým, že z nich robí súčast vztahu spolupráce - kolonizácia je podobne ako u Chamberlaina a Ferryho výhodná pre obe strany, nielen pre kolonizátorov. Ludský pokrok a metropolitné zisky však boli jedno a to isté [Dufour 2014: 330; Schicho 2014a: 237].

Sarraut bol spolu s britským guvernérom Zlatého pobrežia sirom Frederickom Gordonom Guggisbergom a liberálnym reformistom, tajomníkom Medzinárodnej misionárskej rady, Josephom H. Oldhamom, jedným z najvýznamnejších osobností v otázke koloniálneho vzdelávania. Všetci traja spájali ekonomický a sociálny rozvoj a posunuli kolonializmus ku „kolonializmu s ludskou tvárou“ [Schicho 2014a: 243]. Autoritársku guvernmentalitu tak diskurzívne podopreli o jej liberálny náprotivok. Robili tak však do velkej miery účelne. Primárnym ciel'om „bolo zaistit ekonomické zisky pre metropolu popri zaistení imperiálnej moci a medzinárodného uznania" [ibid.: 222]. Pre Oldhama bol prvotný rozvoj ludí a až potom mal nasledovat rozvoj teritória. „Toto bol rozdiel medzi politikou materiálneho vykoristovania a ,úprimnou politikou rozvoja" [Hodge 2007: 139].

Bol to najmä rast exportu surovín a udržanie politickej kontroly, ktoré si vyžadovali vyškolenie polnohospodárov, remeslníkov, úradníkov, baníkov ako aj miestnu elitu [Schicho 2014a: 222]. Termín rozvoj tak začal v sebe zahŕňat aj vzdelávanie. O aké vzdelávanie išlo? Čo presne znamenal rozvoj v otázke vzdelávania?

Cielom Guggisberga a Sarrauta bolo tzv. adaptované vzdelávanie a výcvik charakteru. V prvom prípade išlo o upravenú formu výučby, ktorá by brala ohlad na africké prostredie a zaistovala by rešpekt $\mathrm{k}$ tradíciám a najmä rurálnemu prostrediu a polnohospodárstvu. Súčastou argumentácie $\mathrm{v}$ prospech vzdelávania kolonizovaného obyvatelstva bola potreba 
kvalifikovanej pracovnej sily schopnej zaistit ekonomický rozvoj pre potreby metropole [Usuanlele 2014: 256]. Najdôležitejšia bola „ekonomická užitočnost’ masového vzdelávania“" [Sarraut in Schicho 2014: 234]. Pre skutočnú prax však okrem zrejmého sebazáujmu bola charakteristická improvizácia a nekoherentnost'. Miestne vlády, misionári, koloniálni osadníci a samotní Afričania tahali prax vzdelávania rôznymi smermi [Hodge 2007: 134].

Ďalším cielom bolo, aby koloniálne vzdelávanie formovalo charakter miestnych. Tí sa mali zlepšit vo vytrvalosti, dôslednosti, poriadku, čistote, dochvílnosti, hospodárnosti, striedmosti, sebakontrole, poslušnosti, spolahlivosti, úprimnosti, rešpekte k rodičom a zodpovednosti [Schicho 2014a: 228]. Na tomto základe malo vzdelávanie vychovat absolventov dostatočne rešpektujúcich význam civilizácie na to, aby napríklad po boku francúzskych vojakov bránili civilizáciu, teda Francúzsko, v jeho vojnách.

Ďalšou potrebou bolo vychovat miestne elity, ktoré boli nevyhnutné pre „organizovaný a disciplinovaný pokrok" [Guggisberg in ibid.: 234]. Slovami guvernéra Francúzskej západnej Afriky v rokoch 1923-1930 Julesa Carda bolo cielom „inštruovat masy a ovládnut elity“ [Carde in ibid.]. Tie mali byt dostatočne schopné na to, aby slúžili záujmom impéria, ale zároveň nie príliš vzdelané na to, aby sa zaoberali protikoloniálnymi snahami [Kelemen 2009: 196]. Klúčové bolo vzdelávanie smerujúce $\mathrm{k}$ rešpekte $\mathrm{k}$ civilizácii ako hodnote, ktorá by zamedzila odporu voči kolonizátorom. Guggisberg odmietal hned' budovat aj univerzity, aby sa na ne nedostali elity, ktoré neprešli potrebným tréningom charakteru [Schicho 2014: 233]. Na strane kolonizátorov panovala obava z nárastu proti-koloniálnych nálad a zo vzdelávania afrických nacionalistov [Usuanlele 2014: 262]. Vo všeobecnosti platilo, že vzdelanie sa okrem základného týkalo len velmi malej časti obyvatelstva a išlo naň minimum zdrojov, napriek požiadavkám miestnych elít [pre Nigériu pozri ibid.: 256, 260, pre Tanganiku pozri Eckert 2004: 476].

Rovnako dôležitou otázkou ako v prípade vzdelávanie je: Čo presne znamenal rozvoj $\mathrm{v}$ oblasti zdravia? Koloniálna politika v tejto oblasti, mala v období neskorého kolonializmu podobný ciel ako vzdelávanie - prostredníctvom prevencie a dalších verejných politík zaistit zdravie koloniálneho obyvatel'stva, ktoré bolo nevyhnutné pre ekonomický rozvoj [Bruchhausen 2014: 208; Packard 1997: 94]. Ludia samotní boli kapitálom [Hodge 2007: 119]. Od dvadsiatych rokov 20. storočia došlo k posunu v tejto oblasti od zdravotníckej politiky, ktorá mala urobit trópy „,vhodné pre Európanov“ k zdravotníckej politike viac zameranej na miestnych [Hodge 2007: 72, 121]. Správa Williama Simpsona, vedúceho katedry hygieny na londýnskej King's College už v roku 1909 tvrdila, že zdravie Afričanov bolo nemenej dôležité ako zdravie Európanov pre rozvoj kolónií [ibid.: 79]. V roku 1925 sa v Správe Východoafrickej komisie britskej vlády zo zdravia miestneho obyvatel'stva stal ciel sám o sebe. Dôvodom však bola Simpsonova obava z rozširovania epidémií pozdľž železnice. Vo svojich správach zdôrazňoval ekonomické imperatívy zdravotníckej politiky a koloniálneho rozvoja [ibid.: 83]. Hoci dominantnou legitimizáciou zdravotnej politiky bol vlastný záujem kolonizátorov, existovali aj altruistické odôvodnenia zdravotníckych koloniálnych zásahov a to najčastejšie medzi misionármi a lekármi [Bendix 2016: 9].

Koloniálna medicína sa teda mala venovat africkému obyvatelstvu „z humanitárnych ako aj ekonomických príčin" [Bruchhausen 2014: 209]. Reálne vzhladom na politiku finančnej sebestačnosti kolónií $\mathrm{k}$ zásadnému posunu $\mathrm{v}$ zdravotnej starostlivosti nedošlo [Bruchhausen 2014: 209; Packard 1997: 94; Hodge 2007: 125]. 
Za významný problém bol v 20. rokoch považovaný nízky počet koloniálneho obyvatel'stva a vysoká úmrtnost' [Hodge 2007: 123, 167; Bendix 2016; van Beusekom 1999; Schicho 2014b: 71]. Populačný pokles bol zdôvodňovaný vnucovaním modernej európskej kultúry a rozpadom tradičných miestnych komunít a miestnymi zvykmi vychádzajúcimi z útlaku žien [Bendix 2016: 2-3].

Širším problémom koloniálneho zdravotníctva bola neriešená otázka pôvodu chorôb miestneho obyvatel'stva a jeho decimácie počas predchádzajúcich genocíd na začiatku 20. storočia. To umožnilo prezentovat' koloniálnu zdravotnícku politiku ako altruistickú, hoci len reagovala na stav, ktorý samotná kolonizácia v mnohom zapríčinila [Hodge 2007: 122]. Liberálne prvky počas kolonializmu by preto nemali slúžit na jeho rehabilitáciu [Duffield - Hewitt 2009a: 10]. Tento typ kolonializmu je neoddelitel’ný od násilia založenom na rasizme. Hoci samotné násilie bolo liberálmi kritizované, zároveň bolo nevyhnutné pre pokračovanie imperiálneho dobývania. Liberálny kolonializmus iba tvrdil, že vie vládnut humánnejšie a preto efektívnejšie, ako jeho militarizovaná, národy vyhladzujúca alternatíva [ibid.].

Výdavky na rozvoj v 30. rokoch išli poväčšine na výstavbu ciest. Práve tu dobre vidno využitie orwelovského doublespeaku. „To, čo bolo určené na sociálne služby, bolo v skutočnosti použité na prácu spojenú s kapitálom“ [Koponen 2014: 53]. Až neskôr boli prostriedky použité na vzdelávania a zdravotnú starostlivost', aj ked’ nad’alej len do vel'mi malej miery [Schicho 2014b: 82].

Od druhej polovice tridsiatych rokov 20. storočia nadobudol v britskom diskurze rozvoj význam v zmysle zlepšovania sociálnych podmienok obyvatel'stva a jeho blahobytu [ibid.: 50, 53]. V roku 1935 premiér MacDonald požadoval „omnoho agresívnejší blahobytno-rozvojový prístup“ [Bruchhausen 2014: 213]. Hoci Zákon o koloniálnom rozvoji a blahobyte z roku 1940 ešte poukazoval na oddelený význam pojmov blahobyt a rozvoj, napríklad formulku „rozšírenie medicínsky služieb“ v memorande riaditela medicínskych služieb Ústrednej rozvojovej rady v Tanganike, R. R. Scotta, o dva roky neskôr nahradila formulácia „budúcnost̉ rozvoja medicínskych služieb“ [ibid.: 214]. Postupne tak dochádzalo k splynutiu ekonomického významu pojmu rozvoj s neekonomickým - zdravotným a sociálnym, hoci ešte v pät’esiatych rokoch bol rozvoj spojený viac s fyzickou infraštruktúrou.

Už od štyridsiatych rokoch však rozvoj neznamenal iba rast produkcie a produktivity a konštruktívne vykoristovanie prostredníctvom vývozu tropických produktov. Rozvoj sa začal zaoberat miestnou potravinárskou produkciou, či ochranou pôdy a zdravotníctvo sa začalo zaoberat' nielen Európanmi ale aj zdravím vidieckeho obyvatel'stva. „Rozvoj začal znamenat zlepšovanie sociálneho a ekonomického blahobytu kolonizovaného obyvatel'stva prostredníctvom rozumnej ekologickej a populačnej správy“ [Hodge 2007: 178]. Násilná koloniálna politika tak bola minimálne rétoricky doplnená o svoju liberálnu stránku. Zároveň rozvoj znamenal modernizáciu prostredníctvom experimentu, ktorého laboratóriom bola Afrika. Tým došlo k posunu od rozvoja ako prinášania svetla poznania k rozvoju ako experimentálnej aktivite [Bonneuil 2001: 280].

Väčšina investícii však nad’alej išla na budovanie železníc a fyzickej infraštruktúry, ktorá slúžila získavaniu prírodných zdrojov a nie na sociálne služby pre Afričanov [Hodge Hödl 2014: 11]. Snaha maximalizovat produkciu potravín a tažbu surovín po Druhej svetovej vojne viedla k označovaniu tohto obdobia historikmi a historičkami názvom „druhá 
koloniálna okupácia“ [Low - Lonsdale 1976: 13]. Jej súčastou bol okrem nárastu investícií [pre Francúzko pozri Coquery-Vidrovitch 1976a: 40] výrazný nárast významu expertov pri spravovaní impéria, ktorí dokonca počtom prevýšili administratívnych úradníkov [Chambers in Bonneuil 2001: 265].

Pojem rozvoj sa presadil aj v kolóniách a stal sa $\mathrm{z}$ neho ciel,', na ktorom sa zhodli všetci vrátane miestnych hnutí a politických vodcov [Hunter 2014: 96]. Podobne ako v 50. rokoch pojem ekonomický rozvoj v zmysle zvyšovania výroby umožnil konsenzus medzi Západom a Sovietskym zväzom a Ćínou [Toye - Toye 2006: 35] a dnes pojem rozvoj spája najrôznejšich aktérov [Ziai 2013: 133], tak aj sila maendelea (rozvoj po swahilsky) tkvela v jeho širokom význame a schopnosti spojit protichodné záujmy kolonialistov, kolonizovaných ako aj medzinárodných a mimovládnych organizácií [ibid.: 98, 99].

Pojem rozvoj nadobudnutím svojho sociálneho významu nahradil pojem civilizácia. Tento sociálny význam však neznamenal odpojenie sa od materiálneho vykoristovania kolónií. Pravý opak ukazuje nasledujúca sekcia.

\section{Príčiny zmien v koloniálnej politike}

Vo všeobecnosti platí, že zmeny v koloniálnej politike vychádzali z potrieb koloniálnych hospodárstiev. Posuny k liberálnemu vládnutiu boli spojené so základným imperatívom užitočnosti kolónií pre metropole.

Konštruktívny imperializmus Josepha Chamberlaina mal zaistit produkciu surovín a potravín v kolóniách a zároveň zvýšit ich kúpyschopnost̉ a dopyt po britských priemyselných výrobkoch, ako aj vývoz nezamestnaných z metropole (pre ten istý argument o Francúzsku pozri [Schicho 2014b: 56]. Ďalším cielom bolo uniknút nemeckej a americkej konkurencii [Hodge 2007: 55]. Prijatie britského Zákona o koloniálnom rozvoji v roku 1929 bolo takisto dôsledkom snahy politikov na oboch stranách spektra bojovat’ s nezamestnanostou v Británii [Bruchhausen 2014: 213; Cooper 2010: 10; Schicho 2014b: 57].

Diskusia ohladom zvyšovania finančných výdavkov na kolónie medzi Ministerstvom financií a Ministerstvom pre kolónie (Colonial Office) sa týkala na jednej strane nechuti míňat peniaze zbytočne a na druhej reakcie, že zvyšovanie výdavkov na vzdelávanie, zdravie a dảlšie základné služby „by zvýšilo produktivitu a viedlo $\mathrm{k}$ rastu, čo by pomohlo vláde zaplatit účty“ [Cooper 1997: 67, pozri aj Bruchhausen 2014: 208-209]. V internom meme z roku 1939 jeden zo seniorných predstavitelov Ministerstva pre kolónie argumentoval v prospech toho, aby pomohli Afričanom stat sa štastnejšími a zdravšími, čo by viedlo $\mathrm{k}$ naplneniu dalších cielov, teda efektívnosti produkcie v kolóniách [ibid.]. Liberálne biopolitické snahy zlepšovat život populácie tak boli spojené s klúčovým imperatívom - užitočnostou tejto populácie.

Sir Henry Moore, asistent ministra pre kolónie, argumentoval v prospech doplnenia pojmu „blaho“ (welfare) do názvu Zákona o rozvoji a blahu kolónií (Colonial and Development and Welfare Act) $v$ roku 1940, pretože ,ak to bude najmä o ,rozvoji $v$ tradičnom zmysle, bude to vyzerat ako keby sme iba chceli íst vykoristovat kolónie, aby sme mohli zaplatit za vojnu“ [in Koponen 2014: 40]. Podla dalšieho úradníka zahrnutie pojmu „blaho“ malo Británii zvýšit morálnu prestíž a urobit z toho politicky velkú vec [ibid.].

Tlak od medzinárodného spoločenstva spolu s kritikou zo strany britskej Labouristickej strany [Kelemen 2009: 194] a Francúzskej sekcie medzinárodných pracujúcich rovnako 
ako aj od menej radikálnych medzinárodných organizácií ako boli Medzinárodný úrad práce alebo Ochrana domorodcov či filantropických mimovládnych organizácíi a od radikálnejšieho Panafrického kongresu alebo Medzinárodného afrického úradu pre služby tiež prispeli k zmenám v koloniálnych politikách [Hodge - Hödl 2014: 13]. V snahe stlmit kritiku zvnútra krajiny sa Ministerstvo pre kolónie snažil kooptovat poslancov, intelektuálov a expertov na koloniálne otázky napríklad do Poradného výboru pre vzdelávanie v kolóniách, ktorý posunul diskusiu smerom od čisto ekonomických záujmov [Hodge 2007: 143]. Frank [2014: 117] analyzujúc esejistickú sútaž banky Barclays pre svojich zamestnancov z roku 1942 a zistil, že „mnoho esejistov vykazovalo jasnú túžbu, aby (zámorské) teritória, v ktorých operovali, prosperovali." Tlak mimo egoistických záujmov teda bol prítomný tiež.

Ďalšou motiváciou pre záujem o blaho kolonizovaných v 30. rokoch bola nemecká požiadavka na navrátenie ,ich“ kolónií a požiadavka Nemcov, Talianov a Japoncov na nové prerozdelenie kolónií. Britským protiargumentom bolo, že odovzdanie kolónií by poškodilo blahobyt a sociálny pokrok miestnych [Alcalde 1987: 74]. Liberálna argumentácia tak zároveň slúžila geopolitickým zámerom.

Hlavným dôvodom pre zmenu koloniálnej politiky v prospech navyšovania financií pre sociálny rozvoj boli nepokoje a štrajky v kolóniách [Cooper 1997: 60; Hodge 2007: 111; Jansen - Osterhammel 2017: 62] spojené s poklesom reálnych miezd v dôsledku Velkej hospodárskej krízy v 30. rokoch a s nárastom počtu obyvatelov, ktorý tiež tlačil na pokles miezd [Hodge 2007: 170]. Kolónie sa mali stat "produktívnejšími a zároveň ideologicky stabilnejšími v zmätku povojnových rokov" [Cooper 1997: 64, pozri aj Eckert 2004: 469]. Tým ako autoritárska forma guvernmentality prestávala postačovat ciel'om vládnutia, bolo nutné ju začat doplňat’ o liberálnu formu nielen v rétorickej rovine.

Strach zo straty kolónií sa netýkal len konkurentov bez kolónií, ale aj obavy, že by násilnosti mohli prerást do skutočného boja za nezávislost'. K najvýznamnejším nepokojom došlo na Jamajke a Trinidade, v Severnej Rodézii, na Zlatom pobreží, či v Mombase v druhej polovici tridsiatych rokov. K štrajkom dochádzalo na plantážach, v baniach a došlo aj na generálne štrajky [Hodge 2007: 181].

Po nich nasledovalo prijate nového britského zákona v roku 1940, ktorý neodkazoval len na rozvoj, ale aj na blahobyt a v roku 1947 Zákon o rozvoji zámorských zdrojov (Overseas Resources Development Act) založil Korporáciu pre koloniálny rozvoj a Korporáciu pre zámorské potraviny, ktoré mali zvyšovat životný štandard a blahobyt kolonizovaných a zaistit export koloniálnych produktov [Hodge 2007: 208].

Tu najlepšie vidno spojenie liberálneho vládnutia s užitočnostou subjektov tohto vládnutia. Francúzska vláda v roku 1946 založila Investičný fond pre ekonomický a sociálny rozvoj (FIDES) a v roku 1949 Fond na podporu polnohospodárstva a ekonomického a sociálneho rozvoja. To bolo prvýkrát, čo boli britská a francúzska vláda ochotné dotovat rozvojové programy v kolóniách aj s cielom zvyšovat životnú úroveň miestneho obyvatelstva [Hodge - Hödl 2014: 15]. V skutočnosti však omnoho viac prostriedkov na investície vygenerovali samotné kolónie [Hodge 2007: 192]. A reálna prax, ako ukazuje nasledujúca čast', uchovávala násilie ako klúčovú zložku koloniálneho vládnutia.

Od štyridsiatych rokov sa rozvoj netýkal už v prvom rade britských problémov, ale problémov priamo v kolóniách [Hodge 2007: 16, 146]. Tie zahŕňali ekologickú devastáciu a prebytočné, nezamestnané, obyvatelstvo [ibid.: 145]. 
Koloniálna rozvojová ideológia však „nebola (...) o ,modernizácii koloniálnych krajín a subjektov“ [Hodge 2007: 7]. Hodge súhlasí s Cowenom a Shentonom, že cielom bolo vytvorit’ štátnu politiku a „presadzovat’ hodnotu komunity tvárou v tvár deštrukcii, ktorú priniesol imanentný proces rozvoja" [Cowen - Shenton 1996: 56-57 in ibid.].

Problémom bola napríklad dovtedajšia polnohospodárska politika spôsobujúca eróziu pôdy. Dôsledkom bola snaha rozvíjat zdroje impéria udržatelným spôsobom a chránit ich tak, aby ich bolo možné využívat’ v budúcej kapitalistickej produkcii a zvyšovat' export [Hodge 2007: 111; Schlauß 2014: 151].

Riešenia koloniálnych problémov vychádzali z domácej formy vládnutia - modelu štátu blahobytu a vyjednávania vo vzt’ahoch medzi zamestnancami a zamestnávatel'mi. Tie pre britské elity len reprodukovali terén pre vyjednávanie známy z metropole [Cooper 1996: 16].

Celkovo teda platí, že príčiny zmien v koloniálnej politike boli ekonomické, environmentálne a bezpečnostné. Altruistická rétorika bola ale tiež prítomná. Reálne vynakladané množstvo prostriedkov na sociálny rozvoj však vedie väčšinu autorov a autoriek k záveru, že motiváciou boli najmä vlastné záujmy kolonizátorov. Otázkou ostáva, čo konkrétne sa v rámci koloniálneho rozvoja dialo.

\section{Prax koloniálneho rozvoja}

Hlavná diskusia medzi súčasnými historikmi a historičkami koloniálneho rozvoja sa týka otázky konkrétnych materiálnych praktík priamo v kolóniách a toho, ako tieto praktiky ovplyvňovali diskurzívne premeny [pozri Hodgson 2000: 29-30; Cooper 2010: 8]. Samotná konceptualizácia rozdelenia koloniálneho vládnutia na liberálne a autoritárske tu naráža na neusporiadanost’ reálnej praxe tohto vládnutia.

Agenda neskorého kolonializmu vychádzala viac zo skúseností koloniálnych úradníkov s konkrétnou správou oblastí, ktoré administrovali a s konkrétnymi problémami, s ktorými sa potýkali než z Londýna. Oni a špeciálni poradcovia a experti Ministerstva pre kolónie boli klúčovými aktérmi pri tvorbe a výmene ideí [Hodge 2007: 5].

Podla Hodgea „bola najnápadnejšou črtou britského kolonializmu v 20. storočí rastúca dôvera vo vedu a expertízu spojená s novými byrokratickými kapacitami štátu rozvinút prírodné a ludské zdroje impéria“ [ibid.: 8, 42, pozri aj Bonneuil 2001: 260]. Na skúsenostiach založená miestna správa a politika však mala voči univerzálnej vede častejšie navrch [ibid.: 15].

Konkrétna prax sa dá sledovat' na dvoch úrovniach. Jednou boli konflikty medzi expertmi a úradníkmi v metropolách na jednej strane a expertmi a úradníkmi v kolóniách na strane druhej. „Britskí miestni úradníci viac alebo menej úspešne bojkotovali alebo aspoň spomalovali modernizačné iniciatívy navrhované v Londýne“ [Eckert 2004: 470, pozri aj Hodge 2007: 226-227]. Napríklad segregácia Európanov od miestnych navrhovaná expertmi v metropole zo zdravotných dôvodov bola miestnymi koloniálnymi úradníkmi odmietaná [Hodge 2007: 86]. Títo úradníci mali tiež obavu zo zmien miestnej kmeňovej štruktúry v dôsledku rozvojových projektov, ktoré by ohrozili spolu s autoritou miestnych náčelníkov aj ich vlastnú autoritu [Eckert 2004: 471, 485; Hodge 2007: 229].

Druhou úrovňou boli konflikty medzi miestnym obyvatel’stvom a koloniálnymi úradníkmi. Napríklad v prípade snahy kolonizátorov o zväčšovanie produkcie preferovali 
Sukumčania v Tanganike zväčšovanie obrábacej plochy, kým miestni úradníci intenzifikáciu produkcie [Hodge 2007: 220]. Neprekonatel'nou bariérou bol jednoducho nedostatok spolupráce zo strany Sukumčanov [ibid.: 217]. „Väčšina Tanzánčanov bola celkom úspešná $\mathrm{v}$ rozhodovaní sa o vlastných životoch ignorujúc štátne snahy o sociálny rozvoj" [Ecekrt 2004: 488]. Na celkové presadenie svojej vízie rozvoja koloniálny štát ešte v 20. rokoch nemal dost' vojenskej a finančnej podpory [Hodge 2007: 88]. Bol nútený sa o moc delit’ s miestnymi vládcami využívajúc nepriamu vládu. Väčšina polnohospodárskej produkcie ostala mimo jeho dosah [Bonneuil 2001: 268].

Ucelená štúdia polnohospodárskeho rozvoja pod správou Nigerského úradu (dnešné Mali) v rokoch 1920-1960 [Beusekom 2000] dobre ukazuje ako snaha rozvíjat miestnych a ich polnohospodárske praktiky nefungovala a ako koloniálni experti napokon museli ustúpit a akceptovat tradičnú prax a poznanie miestnych rolníkov [pre ten istý argument z oblasti Konžskej panvy pozri Bonneuil 2001: 271-273].

Základný rozpor bol v snahe dosiahnut intenzívnejšie obrábanie pôdy a produkovat’ viac monokultúr. Proso mala nahradit ryža, ako sa však ukázalo, pôda nebola vhodná na jej pestovanie. Dôsledkom bolo, že miestni rolníci pestovali stále viac mimo územie spadajúce pod správu projektového úradu.

Súčastou „racionalizácie“ produkcie mala byt’ celková transformácia spoločnosti - vytvorenie inštitúcie súkromného vlastníctva, posun od velkých viacčlenných rodín k nukleárnym rodinám a postupná civilizácia miestnych. Napríklad v Ugande sa bohatstvom malo stat vlastnenie vecí ako bicyklov alebo lámp a peniaze mali nahradit dobytok ako formu kapitálu [Schlauß 2014: 156-159]. Koloniálna guvernmentalita [Scott 1995] či koloniálny liberalizmus [Merefield 2009] alebo liberálny imperializmus [Duffield 2010], mali zaistit', aby k získavaniu bohatstva nedochádzalo len brutálnymi praktikami dobyvatelov, ale tento spôsob vládnutia mal pôsobit na podmienky miestnej občianskej spoločnosti. Tie by transformovali správanie a zvyky koloniálnych subjektov, aby boli modernými subjektami produktívnymi v rámci koloniálneho impéria [Scott 1995: 200, 207]. Vládnutie prostredníctvom metód založených na dobrovolnosti malo byt efektívnejšie a udržatelnejšie ako na násilí založené autoritárske vládnutie [Duffield 2010: 42]. Snahy napríklad o zavádzanie súkromného vlastníctva, však viedli k rozdelovaniu pozemkov, zadíženosti, nadmernému využívaniu pôdy a ohrozeniu sociálneho rámca $\mathrm{v}$ rurálnych komunitách, teda presne proti tomu, o čo usilovali rozvojové iniciatívy [Scott 1995: 239-240]. Od zavádzania súkromného vlastníctva a námezdnej práce tak koloniálne autority upúštali. Kým oficiálna rétorika usilovala o oba prístupy - vytváranie racionálnych egoistov v modernej občianskej spoločnosti a komunity v tradičnej spoločnosti, napokon vláda bola nútená presadzovat komunitný rozvoj [ibid.: 198] a sociálna organizácia miestnych spoločností sa mala menit iba postupne [in ibid.: 195].

Pre získavanie poznatkov na postupnú modernizáciu miestnych bola dôležitá antropológia, ktorej úlohou bolo skúmat lokálne jazyky, tradície, či zvyky [Hodge 2007: 48-49]. $\mathrm{Na}$ tie potom mohlo liberálne vládnutie pôsobit'. Modernizačný étos pritom nepochádzal z akademických modernizačných teórií, ale naopak, úradníci potrebovali „zmysel toho, kam smerovali dokonca aj ked' nad chodom udalostí strácali kontrolu“ [Cooper 1997: 81, pozri aj Cooper 2004].

Neúspechy v projekte viedli miestnych úradníkov k akceptácii skutočnosti, že preferencia pestovat plodiny mimo projektu nebola vedená primitívnou túžbou po tradičných 
obilovinách a zelenine, ale bola racionálnym rozhodnutím vo svetle nedostatočného zavlažovania, striedajúcich sa období dažda a sucha, klesajúcej úrodnosti pôdy a povinnosti platit poplatky za pestovanie na pôde úradu [Beusekom 2000, pozri aj Hodge 2007: 218]. $\mathrm{S}$ argumentom, že pestované plodiny treba prispôsobit pôde, aby bola pôda správne využívaná, tak ako to robili miestni farmári, pritom prišiel už v 30. rokoch britský chemik Geoffrey Milne z Východoafrickej výskumnej stanice pre polnohospodárstvo. Spolu s dalšími vyvrátili predstavu, že africká pôda je úrodná pre akékolvek plodiny určené na export [Hodge 2007: 154-157]. V 40. rokoch však v Koloniálnom poradnom výbore pre polnohospodárstvo a zdravie zvierat v Londýne (Colonial Advisory Council on Agricultural and Animal Health, CAC) dospeli k záveru, že produkcia plodín pre zahraničné trhy je možná iba s využitím umelých hnojív [ibid.: 234].

Prijatie poznania miestnych rolníkov však neviedlo $\mathrm{k}$ zmene sociálne evolučného prístupu [Beusekom 2000: 96]. Problémom nadalej bola „mentalita extenzívneho polnohospodárstva“ [ibid.: 97]. K zmenám dochádzalo len z nutnosti zachránit neúspešný projekt.

Popritom treba mat̉ na pamäti, že súčastou projektov v tom čase bola nútená práca. Guvernér Pobrežia slonoviny, André Latrille, hovoril v roku 1943 o polovičnom otroctve [Schicho 2014b: 75]. Dôsledkom násilia boli hromadné úteky rolníkov a ich rodín. Ked’ bola v roku 1945 nútená práca zrušená, koloniálni úradníci využívali pokuty a nútené vystahovania, aby dosiahli disciplínu medzi miestnymi [ibid.: 86]. Zmieňovaný projekt v Sukumalande na začiatku 50. rokov potom viac pripomínal policajnú operáciu než pol'nohospodársky projekt [Hodge 2007: 218]. Všetky infraštruktúrne projekty ako železnice, či zavlažovanie boli budované pomocou nútenej práce, pri ktorej umieralo obrovské množstvo pracujúcich [Hodge - Hödl 2014: 12]. Termín liberálny imperializmus tak dobre spája liberálnu guvernmentalitu - vládnutie prostredníctvom foucaultovského riadenia správania sa, ktoré neobsahovalo násilie a autoritársku guvernmentalitu spojenú s násilím, ktoré bolo v pozadí neustále prítomné a aj často využívané.

Nemalo by sa však zabúdat, že v rámci koloniálneho systému mohli byt niekedy projekty vítané, hoc aj vo svojich cieloch celkovo zlyhali, napríklad ak prinášali peniaze do regiónu, ako v prípade pestovania kešu orechov v Tanganike [Koponen 2014: 49; Rizzo 2006: 217]. Zároveň podla Hodgea, „z pohladu kultúrnej a ekologickej citlivosti začiatku 21. storočia boli mnohé princípy neskorých koloniálnych iniciatív, možno prekvapivo hodné pochvaly“ a „boli dláždené dobrými úmyslami“ [Hodge 2007: 262]. Vládny úradníci v Londýne si boli vedomí niektorých vlastných chýb v minulosti a dôsledkov neobmedzovaného vykoristovania. Odtial plynula snaha konzervovat pôdu a tradičný spôsob života, ktorého rozvrat spôsobovali kontradikcie kapitalistického vývoja v kolóniách. Práve tu vidí Hodge počiatky rozvojového aparátu, ktorý depolitizuje problémy koloniálnej chudoby a neporiadku zo štrukturálnych a politických otázok do otázok technických [ibid.: 19, 111, 153, 263, pozri aj Bonneuil 2001: 266]. Otázka práce a miezd sa už v kolonializme stala otázkou ekonomického a sociálneho plánovania a rozvoja a nie otázkou mocenského konfliktu a bola spojená so snahou uchovat tradičný farmársky spôsob života, ktorý mal bránit migrácii nezamestnaných [ibid.: 264-265], ale zároveň bolo cielom v konečnom dôsledku vytvorit trhovú ekonomiku orientovanú na export [Schlauß 2014: 162].

Eróziu pôdy začiatkom 20. rokov zdôraznila Juhoafrická komisia pre vyšetrovanie sucha. Za problematické boli považované najmä africké polnohospodárske metódy 
- nadmerné spásanie, spal’ovanie lesov, intenzívne pestovanie pre krátkodobý zisk, ohradzovanie oviec a dobytka [Hodge 2007: 159]. Problémy s klesajúcimi výnosmi v dôsledku poklesu úrodnosti pôdy alebo jej vysúšania boli zaznamenané aj v Ugande, Tanganike a západnej Afrike a z ochrany pôdy sa stala hlavná priorita [ibid.]. Ciel'om bolo uchovat' miznúci prírodný kapitál a zaistit ho pre budúcu akumuláciu a export [ibid.: 164, 111; Schaluß 2014: 151].

Ďalším problémom, ktorým sa koloniálna mocnost’ v rámci guvernmentálneho riadenia správania sa zaoberala bol rozvrat miestnych komunít a jeho riešením bol „komunitný rozvoj“. Ciel’om komplexných návrhov zlepšit’ vzdelanie, zdravie a ekonomický život komunity bolo bojovat proti migrácii rol'níkov do mesta a tak upravovat imanentný rozvoj kapitalizmu, ktorý takúto migráciu vyvolával. Zastavit ju mala obnova tradičného dedinského života idúca proti prílišnému individualizmu [Hodge 2007: 187-188, 250-251].

Od 40. rokov sa snaha vysporiadat' sa s problémami britskej nezamestnanosti prostredníctvom koloniálneho rozvoja posunula k snahe riešit problémy nezamestnanosti a migrácie do miest priamo v kolóniách [Hodge 2007: 16]. Súčastou koloniálnej guvernmentality sa tak v rámci rozvoja stalo aj sociálne zabezpečenie, proti ktorému sa stavala koloniálna loby v metropoli [Schicho 2014b: 74, 82]. Až do Druhej svetovej vojny bola téma sociálneho zabezpečenia v kolóniách do vel'kej miery odbývaná odkazom na tradičnú africkú solidaritu, vd’aka ktorej boli štátne schémy údajne zbytočné. Iba Európania mali reálne nárok na sociálne benefity. Už v roku 1909 nariadil guvernér Nemeckej východnej Afriky povinnost' zamestnávatelov garantovat zdravotnú starostlivost’ svojim zamestnancom, avšak toto opatrenie bolo napĺňané len zriedka [Eckert 2004: 473]. V roku 1923 Briti zaistil drobné kompenzácie za pracovné úrazy zamestnancom v priemysle. V roku 1942 potom založili penzijný fond pre nižších tanganických úradníkov. Čoskoro však bolo zrejmé, že takúto sociálnu politiku museli ako Francúzi, tak aj Briti opustit kvôli privysokým nákladom, ktoré by zahrnutie aj iba malej časti afrických pracovníkov znamenalo [ibid.: 472, 474, 475; Schicho 2014b: 82-83].

Stručný náčrt koloniálnej praxe ukazuje kontinuitu so súčasnou rozvojovou spoluprácou. Hoci v roku 1955 bolo aktívnych vyše sedemdesiat vel'kých polnohospodárskych projektov, už v tomto čase bolo zrejmé, že vel’a z nich zlyhalo. Iniciatíva tak bola vrátená spät miestnym koloniálnym vládam [Hodge 2007: 208-209]. Napríklad v prípade projektu v Sukumalande bolo hlavným problémom, že išlo o dovtedy nevyskúšanú mechanizáciu pol'nohospodárstva vo vel'kom meradle [ibid.: 213]. V prípade známej schémy na pestovanie arašidov v Tanganike boli problémom nesprávne dáta dažd’ových zrážok, chýbajúca hĺbková analýza pôdy, stroje nevhodné do trópov, choroby, ktorým arašidy nevedeli vzdorovat, rozhodnutia prijímané v Londýne, ktoré nezohladňovali miestne zistenia a problémy spojené s náborom zamestnancov [Rizzo 2006: 210].

Čo konkrétne teda spája koloniálny rozvoj s dnešným rozvojom? Už v 50. rokoch poukazovali výskumníci v kolóniách na skutočnost', že sa v rozvojových projektoch používali tie isté prístupy ako v 30. rokoch. To isté platilo o 70. rokoch [Bonneuil 2001: 259]. K poučeniu z chýb minulosti jednoducho nedošlo a „čo je horšie, mnoho z účastníkov diskusií o rozvoji si nebolo vedomých, že by k akýmkolvek chybám došlo“ [Hodge 2007: 271]. Nevšímanie si histórie pri štúdiu súčasného rozvoja však pokračuje [Jenkins 2006: 2; Easterly 2002], aj ked’ tu citované zdroje ukazujú pozitívnu zmenu v tomto ohlade. O akých 
diskontinuitách a kontinuitách sa dá hovorit’ medzi kolonializmom a súčasnostou? Nasledujúce dve časti poukazujú na odlišnosti a podobnosti v rozvoji v ére liberálneho kolonializmu a v ére liberálneho svetového poriadku, ktorého základnými jednotkami sú formálne rovnocenné suverénne štáty.

\section{Od civilizácie $\mathrm{k}$ rozvoju}

V čom rozvojový diskurz ako základ postkoloniálneho globálneho vládnutia predstavuje diskontinuitu voči koloniálnemu diskurzu? Základnou odlišnostou je posun od biológie ku kultúre a geografii v otázke rasizmu a od nemennej nerovnosti k potenciálnej rovnosti v otázkach identity.

Hlavným prvkom neskorej koloniálnej odlišnosti medzi rasami bola ich nemennost’ a nepremostitel'nost' [Cooper 1997: 75; Koponen 2014: 58]. Tá v 30. rokoch 19. storočia nahradila skoršie, na kultúrnej odlišnosti založené vízie o prerobení obyvatelov kolónií na obraz kolonizátorov [Hodge 2007: 35; Merefield 2009: 19]. „V koloniálnom diskurze (... tak) nebolo možné nájst' konštitutívne prvky jednej skupiny v inej skupine“ [Dufour 2014: 331]. Jedni boli definovaní ako opak druhých, ako bud' civilizovaní alebo necivilizovaní, schopní alebo neschopní si vládnut'. Biologický základ rasových teórií umožňoval túto nemennost' potvrdit vedecky, aj ked' rasa nebola nikdy čisto biologickým konštruktom a vždy obsahovala aj kultúrne charakteristiky, či geografické faktory.

V rozvojovom diskurze došlo k posunu smerom od rás ku geograficky definovaným entitám. Zatial' čo počas kolonializmus sa hovorilo o divochoch, barbaroch, či vyspelých civilizáciách alebo rasách, $v$ rozvojovom diskurze sa začalo hovorit’ o oblastiach alebo krajinách [Ziai 2006: 37]. Nie ludia sú primárne nerozvinutí alebo podrozvinutí, ale priestor, v ktorom sa nachádzajú. Krajina je rozvinutá alebo rozvíjajúca sa. Zároveň už neplatí, že necivilizovaných civilizujú civilizovaní, ale nerozvinutí sú schopní sa rozvíjat sami iba s pomocou rozvinutejších [Ziai 2016: 49]. S nástupom SDGs dochádza v tomto ohlade $\mathrm{k}$ čiastočnému posunu najmä $\mathrm{z}$ ekologických dôvodov a aj tzv. rozvinutí sú problémom [Ziai 2016: 194-207].

A napokon, pôvodne neprekonatelný rozdiel medzi My a Oni sa mení na potenciálnu rovnost'. Protikladom rozvinutosti viac nie je necivilizovanost' divochov neschopných rozvoja, ale podrozvinutost' alebo rozvíjanie sa. Iný sa tak stáva súčastou priestoru Ja, hoci ostáva na jeho okraji [Dufour 2014: 332-333]. Pregnantne túto zmenu vyjadruje francúzsky preklad Rezolúcie OSN 198, ked’ termín „underdeveloped countries“ bol preložený ako „nedostatočne rozvinuté krajiny“ [ibid.: 333]. Krajiny nie sú nerozvinuté, len nedostatočne rozvinuté. V koloniálnom slovníku došlo od 20. rokov minulého storočia najprv v akademických kruhoch ku kritike rasového myslenia. V 40. rokoch už bola rasová nadradenost’ nahradená kultúrnou, ktorá však využívala vel’mi podobné spôsoby argumentácie ako civilizačný diskurz [Cooper 1997: 87, poznámka 21; Eckert 2004: 474]. Biologický rasizmus bol definitívne zdiskreditovaný Holokaustom, neznamená to však, že na rase založené argumenty $\mathrm{v}$ rôznych podobách nepretrvávajú.

Bola to práve rovnost' $v$ rozvojovom diskurze, ktorá umožňovala kolonizovanému obyvatel'stvu, aby svoje požiadavky formulovalo v jazyku práv a z nich vyplývajúcich nárokov a bola to predstava lineárneho rozvoja, ktorá vytvorila diskurz pre formuláciu týchto požiadaviek. V akých formách však koloniálny rozvoj pokračuje dodnes? Kde konkrétne 
dnes nájdeme súčasti liberálnej koloniálnej guvernmentality? A v čom dnešné rozvojové vládnutie obsahuje násilie (ak vôbec)?

\section{Koloniálne kontinuity}

Základným argumentom mnohých historikov rozvojových snáh je kontinuita medzi koloniálnym rozvojom a rozvojovou érou po dekolonizácii. Hlavnou diskurzívnou podobnostou je nemeniaca sa štruktúra diskurzu rozdelujúca l’udí na dve časti a pretrvávajúca eurocentrická predstava jednosmerného rozvoja [Ziai 2006: 39-41].

V koloniálnom aj rozvojovom diskurze je svet rozdelený na dve časti - rozvinutú/civilizovanú a rozvíjajúcu sa/zaostalú. Tí, čo sú rozvinutí predstavujú vzor pre tých, ktorí sa rozvíjajú a za dôležité je považované to, v čom práve oni vynikajú. Tak ako predtým vynikali Európania v civilizovanosti, tak v rozvojovom diskurze vynikajú v HDP na osobu, modernizácii výroby, či v počte vysokoškolsky vzdelaných občanov.

Rozvojový diskurz tak nad’alej postuluje predstavu, že rozvoj je lineárny. Na konci cesty rozvoja je rozvinutá (často európska) priemyselná krajina, ktorá určuje, čo je to rozvoj a ako sa k nemu dostat'. Odlišné spôsoby života ostávajú mimo možných predstáv o civilizácii, alebo rozvoji a tieto predstavy sú často považované za prekážky v rozvojovom úsilí. Rozvojový diskurz je tak rovnako ako ten koloniálny eurocentrický.

V praxi existuje nad’alej možnost' usmerňovat' napredovanie spoločnosti prostredníctvom vzdelávania a d’alších sociálno-technologických zásahov spojených s prvkami autoritárstva až násilia [Schicho 2014b: 96-98; Burton - Jennings 2007: 6-7; Schneider 2006]. Rozvojový paternalizmus koloniálnej guvernmentality je tak nad’alej na globálnom Juhu prítomný. Posunom je zmena poručníkov z koloniálnych pánov na miestne vlády, prípadne mimovládne organizácie. Pokračuje tak rozdelenie Afričanov na elity (ktoré získali západné vzdelanie) a na nevzdelané masy, ktorým majú tieto elity vládnut' [Burton - Jennings 2007: 8-9]. Všetci aktéri však prostredníctvom (mimo)vládnych zásahov usilujú o dosiahnutie rozvoja. Väčšina velkých rozvojových projektov, ktoré boli začaté počas neskorého kolonializmu pokračovali po získaní nezávislosti [Bonneuil 2001: 264]. Podobné sú aj autoritárske a násilné spôsoby pri presadzovaní rozvoja. Tak ako boli miestni nútení sa podriadit koloniálnym vládcom, tak sú dnes mnohí vystahovávaní vlastnými vládami napríklad kvôli priehradám, alebo sú pripravovaní o možnost̉ reprodukcie v mene rozvoja [Ziai 2006: 40, pozri aj Nandy 1995; Kothari - Harcourt 2004]. Liberálna guvernmentalita je tak nad’alej dopĺňaná o tú autoritársku.

Cielom rozvoja je dnes, rovnako ako v minulosti integrácia krajín globálneho Juhu do svetového hospodárstva. Počas kolonializmu mala a dnes má integrácia slúžit obom stranám. Kým za kolonializmu išlo podla francúzskeho zákona z roku 1946 o celú francúzsku úniu, dnešné Dohody o hospodárskom partnerstve majú slúžit EÚ a zároveň ich partnerom [Schicho 2014b: 98].

Kontinuitu vidno aj v pôsobení mimovládnych organizácií. Počas kolonializmu bola ich funkcia napomáhat pri potláčaní protikoloniálnych bojov tým, že okrem iného ponúkali materiálnu pomoc. Podobnost vidno s pôsobením mimovládnych organizácií v rámci dobrého vládnutia po oslabení štátu neoliberálnymi reformami. Podobnost’ vidno aj v snahe naprávat' zlyhania miestnych. Na príčiny spôsobujúce zbedačenie však nehladeli vtedy a do vel'kej miery nehladia ani dnes [Manji - O'Coill 2002: 571, 582]. 
Ďalším prvkom kontinuity v oblasti rozvoja pred a po dekolonizácii boli odborníci na rozvoj. Mnohí z tých, ktorí boli zamestnaní v britskom Ministerstve pre kolónie sa neskôr zamestnali v medzinárodnom rozvojovom priemysle alebo učili rozvojové štúdiá na vysokých školách, robili výskum, navrhovali vládne politiky a radili medzinárodným a mimovládnym organizáciám [Hodge 2007: 256-262; Hodge 2010; Kothari 2005: 52]. Napríklad za vznikom Organizácie pre výživu a polnohospodárstvo (FAO) stáli úradníci z britského Ministerstva pre kolónie a poradca tohto Ministerstva, lord John Boyd, sa stal generálnym riaditelom FAO.

Mnohí bývalí, najmä francúzski, koloniálni úradníci sa tiež uchytili v Európskom hospodárskom spoločenstve, ktoré vzniklo v roku 1957. Už o rok neskôr bol založený Európsky rozvojový fond pre zámorské teritóriá vybudovaný podla francúzskeho FIDESu. Sem preniesli „koloniálnu psychológiu“, čím Dimier [2008: 434] myslí administratívne metódy adaptované na neo-patrimoniálny spôsob fungovania afrických politických „klientov“.

Výskum založený na rozhovoroch s bývalými koloniálnymi úradníkmi, z ktorých sa stali odborníci na rozvoj ukazuje ako sa títo v rozhovoroch prezentovali ako vo svojej podstate rozvojoví odborníci, ktorí robili rozvojovú prácu ešte počas kolonializmu [Kothari 2005: 56]. Obhajovali „dobrú prácu vykonanú za kolonializmu“ [ibid.: 53], pretože práca pred dekolonizáciou a po nej bola podla nich „, konečnom dôsledku tým istým“ [ibid.: 56].

Ďalším konkrétnym príkladom kontinuity medzi érou pred a po dekolonizácii je participatívny prístup v rozvojovom manažmente, teda základ liberálnej guvernmentality, v ktorom jej subjekty participujú na vládnutí. Participatívny prístup má spoločné základné prvky s tzv. nepriamym vládnutím počas kolonializmu [Cornwall 2006: 66; Hodge 2007: 187; Jansen - Osterhammel 2017: 56]. V oboch prípadoch slúži participácia na kooptáciu a ideologickú konverziu tých, ktorí participujú - či už sú to miestni náčelníci počas kolonializmu, alebo technokratické či politické elity v súčasnosti [Cooke 2003]. Vo francúzskom kolonializme po Druhej svetovej vojne išlo o tzv. „vedenú samostatnost" [Schicho 2014b: 89]. Už v roku 1929 hovoril poslanec britského parlamentu H. Sneed o morálnej zodpovednosti britského parlamentu za požiadavky ludí podriadených britskému impériu proti vykoristovaniu a „za ich participáciu pri rozhodovaní o vlastnom osude“ [in Cornwall 2006: 65]. Lord Hailey autor vplyvného Afrického prieskumu navrhoval nahradit” poručníctvo partnerstvom, hovorca Strany práce, Arthur Creech Jones, požadoval termín, ktorý vyjadrí rovnost' a priatel'stvo a rovnako tak premiér Harold Macmillan hovoril o partnerstve v roku 1942 v Dolnej snemovni [Wolton 2000: 122-123].

Dnešné vlastníctvo v diskurze rozvojových organizácií sa opiera o podobnú formu liberálnej guvernmentality - o podobné kultúrne zmeny v správaní sa, v organizačných štruktúrach a v procese učenia sa na strane príjemcov pomoci, ako tomu bolo počas kolonializmu na strane kolonizovaných subjektov [Cooke 2003: 53]. Koloniálny rozvoj zdôrazňoval transfer techník vládnutia Afričanom vzdelaných misionármi, ktorí by ovládali „moderné spôsoby" [Cornwall 2006: 67].

Analogickú históriu ako koncept participatívneho prístupu má koncept dobrého vládnutia. V britskom koloniálnom kontexte sa odohrávala podobná diskusia ohladom dobrého vládnutia, ako v súčasnosti v medzinárodných finančných inštitúciách. Pre britských imperialistov dobré vládnutie znamenalo rozvoj, modernizáciu a pozápadnenie koloniálneho sveta [Hewitt 2006: 42, 47]. Zároveň však koncept dobrého vládnutia znamenal aj seba-vládu, čím vytvoril paradox nútiaci Britov ostat kvôli rozvoju a zároveň odíst kvôli 
nezávislosti miestnej vlády. V medzivojnovom období sa ale pod seba-vládou myslela takáto vlády v rámci impéria a nie nezávislost'. Podobnost s konceptualizáciou dobrého vládnutia na konci 20. storočia spočíva vo vytváraní konsenzu o konkrétnom (protrhovom) type rozvojových procesov, ktorý v sebe zahŕňa aj sociálne inkluzívne rozhodovanie. Podobne ako počas kolonializmu, aj tu existoval priestor pre radikálnejšie politické požiadavky zo strany mimovládnych organizácii a sociálnych hnutí na demokratizáciu rozvoja. V oboch periódach sa termín dobré vládnutie posunul „z technickej, minimalistickej definície k expanzívnejšiemu, sociálnemu a inštitucionálnemu konceptu“ [ibid.: 56]. V oboch prípadoch dobré vládnutie malo byt๋ „chýbajúcim článkom“ spájajúcim kapitalizmus s demokraciou a $\mathrm{v}$ ani jednom $\mathrm{z}$ prípadov neviedlo k zásadným zmenám - dekolonizácii, ani k opusteniu neoliberálnych politík, aj ked’ sa s takýmito požiadavkami muselo vyrovnávat'.

Zmieňovaný boj proti klesajúcemu počtu obyvatel'stva v kolóniách má svoju kontinuitu v opačnom zasahovaní do verejnej populačnej politiky so snahou o zabránenie rastu obyvatel'stva ešte počas kolonializmu $\mathrm{v} 30$. rokoch a $\mathrm{v}$ dnešnej rozvojovej spolupráci [pre región Kabale v Ugande pozri Carswell 2003]. V oboch obdobiach je cielom ovplyvňovat' množstvo obyvatelov, $\mathrm{v}$ oboch obdobiach je prítomné násilie autoritárskej guvernmentality, v oboch obdobiach je príčinou prílišnej alebo nedostatočnej populácie zaostalost miestnych a kým rétorika sa posunula od koloniálneho sebazáujmu $\mathrm{k}$ humanitárnym motiváciám, $\mathrm{v}$ oboch prípadoch je zrejmé napojenie na národné záujmy. $\mathrm{V}$ súčasnosti okrem snahy o medzinárodnú stabilitu ide aj o záujmy napríklad nemeckých farmaceutických firiem [Bendix 2016].

Analýza ekologických konceptov v Zambii ukazuje dalšiu podobnost̉ so súčasným stavom. To, čo dnes nazývame udržatelným rozvojom, svojim spôsobom existovalo už počas kolonializmu. Po období dominancie predstavy extrémne úrodných trópov, viedol ekologický výskum na začiatku 30. rokov k zmene perspektívy a tropická ekológia začala klást dôraz naopak na neúrodnost miestnej pôdy a potrebu jej ochrany [Speek 2014: 139; Hodge 2007: 146]. V roku 1935 CAC rozhodla o vymenovaní koloniálnych úradníkov, ktorí sa mali zaoberat eróziou pôdy [Hodge 2007: 163]. Ekológia mala slúžit na ochranu pred prílišným využívaním, ktoré viedlo $\mathrm{k}$ sociálnemu a ekologickému rozvratu a zároveň mala zaistit vyššiu produkciu. K rozvoju malo preto dochádzat až po dôkladnom preskúmaní pôdy a zistení, čo by sa dalo pestovat tak, aby nedochádzalo $\mathrm{k}$ jej ničeniu, a to napriek tomu, že existovali praktiky brániace erózii pred koloniálnami intervenciami [pre Ugandu pozri Schlauß 2009: 149-150; Carswell 2003: 9]. Rozvoj bol chápaný v zmysle, že mal „stabilizovat existujúcu rovnováhu v prírode a popritom postupne zavádzat ekologicky zmysluplné zlepšenia a nápravy, ktoré by viedli polnohospodársku evolúciu v súlade s miestnymi predpokladmi“ [Speek 2014: 144]. Napríklad v Ugande usilovala koloniálna vláda o „pokrok prostredníctvom ochrany (polnohospodárskych zdrojov)“ [citované v Schlauß 2014: 146-147]. Na konci 30. rokov a po Druhej svetovej vojne však došlo k obratu a prevážila snaha modernizovat' a mechanizovat polnohospodárstvo, ktorú až do 60. rokov znemožňovala privysoká cena umelých hnojív [Hodge 2007: 257]. Masívne štátne dotácie však napokon viedli k tzv. zelenej revolúcii. Obrat naspät k udržatelnosti prišiel až s tématizáciou limitov rastu začiatkom 70. rokov [Speek 2014: 150].

Ak existuje tolko podobností medzi rozvojom v koloniálneh a postkoloniálnej ére, vynára sa posledná zásadná otázka: aké boli jeho dopady? Čo sa stalo s konfliktom medzi liberálnym a autoritárskym vládnutím v ére suverénnych štátov? 


\section{Záver: Následky koloniálneho rozvoja}

Hoci ciel’om koloniálnej rozvojovej legislatívy vo Franúczsku a v Británii bolo postavit’ impérium na nohy a opätovne ho legitimizovat proti protestom, ktoré prepukali po celom svete, následky koloniálneho rozvoja boli celkom odlišné: „poskytol nástroje imperiálnym mocnostiam ako sa vysporiadat' so stratou moci a udržat' si pritom spojenie s bývalými kolóniami a pocit zmysluplnosti pri formovaní ich budúcnosti“ [Cooper - Packard 1997: 7].

Nanovo definovaný vzt’ah, v ktorom hierarchia viac nebola neprekonatelná, ale obyvatel'om kolónií poskytovala možnost’ sa zapojit do globálnej spoločnosti ako potenciálne rovným občanom, bol vítaný ako elitami, tak neelitnými zložkami obyvatel'stva [ibid.: 1; pozri aj Rahnema 1997: ix]. Pre elity globálneho Juhu sa stal zdrojom podpory pre národné projekty rozvoja a emancipácie, ktoré mohli využit ako mobilizačný mýtus a zároveň legitimizáciu ich niekedy autoritárskych foriem vládnutia [Ziai 2007: 54-55]. Tieto elity prevzali vieru v rozvojový projekt a prostredníctvom rozvojového diskurzu sa vnímali ako moderní oproti spoluobčanom bez vzdelania, ktorých považovali za iracionálnych a zaostalých [Burton - Jennings 2007: 5]. Neelitné časti obyvatel'stva na globálnom Juhu zas dúfali v oslobodenie spod starých i nových foriem podriadenia a zároveň sa necítili viac byt' rasovo inferiórnymi, ale rovnými členmi globálnej spoločnosti. Slub rozvoja v nich takisto vyvolal očakávanie zvyšujúcej sa životnej úrovne. Súc súčastou moderných, osvietených, technologicky vyspelých spoločností si ludia na globálnom Severe ponechali svoju kultúrne nadradenú pozíciu a staronové ekonomické vztahy im zaistil nevyhnutné prírodné zdroje pre ich spôsob života. Politické elity na globálnom Severe si zachovali vplyv v bývalých kolóniách prostredníctvom pôžičiek, rozvojovej pomoci a vdaka nerovnému nastaveniu globálnych ekonomických štruktúr a napokon z už zmienených koloniálnych expertov sa stali rozvojoví experti [Ziai 2007: 55]. Nová diskurzívna konštelácia teda priniesla výhody všetkým zúčastneným skupinám.

Pretrvávajúca predstava o nadmernej populácii na globálnom Juhu v 50. a 60. rokoch ústila do kontinuálnej potreby rozvoja, ktorý by sa s touto populáciou vysporiadal. Napriek tomu, že koloniálne rozvojové iniciatívy zlyhali, rozvojové štruktúry orientované na štátne zásahy ostali aj potom, ako sa koloniálne mocnosti formálne vzdali svojich kolónií [Bonneuil 2001: 260]. Následkom bola pokračujúca expanzia byrokratickej štátnej moci, ktorá stále viac zasahovala do života občanov v mene rozvoja [Hodge 2007: 255]. Súčastou rozvojového aparátu bola pretrvávajúca dominancia vedy, ktorá v prípade polnohospodárstva napokon viedla $\mathrm{k}$ masívnej mechanizácii a využívaniu chemických hnojív so všetkými (pozitívnymi a) negatívnymi dopadmi. Noví vládcovia na globálnom Juhu síce porazili svojich utláčatelov, avšak osvojili si ich rozvojové myslenie a ich cielom sa stalo dokončit v čom ich predchodcovia zlyhali a zaistit aj priemyselný rozmach. Napríklad na vybudovaní (na začiatku rovnostárskejšieho) systému Bretton Woods mali velký podiel vlády Latinskej Ameriky [Helleiner 2014]. Koloniálny rozvoj tak plynule prešiel do postkoloniálnej rozvojovej éry.

V nej je nad’alej prítomná liberálna biopolitika vo vztahu k tým, ktorí majú byt rozvíjaní, pohybujúca sa medzi autoritárskym poručníctvom niekedy spojeným s násilím a dobrovolnostou. Tento základ kolonializmu tak ostáva nezmenený v postkoloniálnej ére. $\mathrm{Na}$ históriu rozvoja sa však až pričasto zabúda a opakujú sa stále tie isté politiky a s nimi aj tie isté chyby. 
Otázka konkrétneho počiatku rozvoja tak ostáva problematickou, ak rozvoj konceptualizujeme prostredníctvom liberálneho a autoritárskeho vládnutia. Hoci o výraznejších materiálnych zásahoch sa dá hovorit’ až od 40. rokov 20. storočia, ideologické základy rozvoja boli (nielen) v kolonializme prítomné omnoho skôr.

\section{Podakovanie}

Táto práca bola podporená Agentúrou na podporu výskumu a vývoja na základe Zmluvy č. APVV-19-0314.

\section{Literatúra}

Abbott, George C. [1971]. A Re-Examination of the 1929 Colonial Development Act. The Economic History Review 24 (1): 68-81.

Alcalde, Javier Gonzalo [1987]. The Idea of Third World Development. Emerging Perspectives in the United States and Britain, 1900-1950. Lanham - London: University Press Of America.

Arndt, H. W. [1981]. Economic Development: A Semantic History. Economic Development and Cultural Change 29 (3): 457-466.

Aspengren, Henrik [2009]. Empire: A Question of Hearts? The Social Turn in Colonial Government, Bombay c. 1905-1925. In. Duffield, Mark - Hewitt, Vernon (ed.). Empire, Development and Colonialism. The Past in the Present. Woodbridge: James Currey, s. 45-58.

Bendix, Daniel [2016]. From Fighting Underpopulation to Curbing Population Growth: Tracing Colonial Power in German Development Interventions in Tanzania. Postcolonial Studies 19 (1): 53-70.

Bonneuil, Christophe [2000]. Development as Experiment: Science and State Building in Late Colonial and Postcolonial Africa, 1930-1970. Osiris 15 (1): 258-281.

Bruchhausen, Walter [2014]. From precondition to goal of development: health and medicine in the planning and politics of British Tanganyika. In. Hodge, Joseph Morgan - Hödl, Gerald - Kopf, Martina (ed.). Developing Africa. Concepts and Practices in Twentieth Century Colonialism. Manchester: Manchester University Press, s. 207-221.

Burton, Andrew - Jennings, Michael [2007]. Introduction: The Emperor's New Clothes? Continuities in Governance in Late Colonial and Early Postcolonial East Africa. The International Journal of African Historical Studies 40 (1): 1-25.

Cooke, Bill [2003]. A New Continuity with Colonial Administration: Participation in Development Management. Third World Quarterly 24 (1): 47-61.

Cooper, Frederick [1996]. Decolonization and African Society. The labour question in French and British Africa. Cambridge: Cambridge University Press.

Cooper, Frederick [1997]. Modernizing Bureaucrats, Backward Africans and the Development Concept. In. Cooper, Frederick - Packard, Randall (ed.). International development and the social sciences: essays on the history and politics of knowledge. Berkeley - Los Angels - London: University of California Press, s. 64-92.

Cooper, Frederick [2004]. Development, Modernization, and the Social Sciences in the Era of Decolonization: the Examples of British and French Africa, Abstract. Revue d'Histoire des Sciences Humaines 10 (1): 9-38.

Cooper, Frederic [2010]. Writing the History of Development. Journal of Modern European History 8 (1): $5-23$.

Cooper, Frederick - Packard, Randall [1997]. Introduction. In. Cooper, Frederick - Packard, Randall (ed.). International development and the social sciences: essays on the history and politics of knowledge. Berkeley - Los Angels - London: University of California Press, s. 1-41.

Coquery-Vidrovitch, Catherine [1976a]. La mise en dépandance de l'Afrique noire. Essai de périodisation, 1800-1970. Cahier d'Études Africaine 16 (61): 7-58. 
Coquery-Vidrovitch, Catherine [1976b]. L’Afrique coloniale française et la crise de 1930: crise structurelle et genèse du Rapport d’ensemble. Revue française d'histoire d’outre-mer 63 (232): 386-424.

Cornwall, Andrea [2006]. Historical perspectives on participation in development. Commonwealth \& Comparative Politics 44 (1): 62-83.

Cowen, Michael P. - Shenton, Robert W. [1996]. Doctrines of development. London - New York: Routledge.

Cowen, Michael P. - Shenton, Robert W. [1999]. The Invention of Development. In. Crush, Jonathan (ed.). Power of Development. London - New York: Routledge, s. 25-41.

Dean, Mitchell [2010]. Governmentality. Power and rule in modern society. London: SAGE.

Dimier, Véronique [2008]. Bringing the Neo-Patrimonial State back to Europe. French Decolonization and the Making of the European Development Aid Policy. Archiv für Sozialgeschichte 48: 433-457.

Duffield, Mark [2009]. Liberal Interventionism and the Fragile State. Linked by Design? In. Duffield, Mark - Hewitt, Vernon (ed.). Empire, Development and Colonialism. The Past in the Present. Woodbridge: James Currey, s. 116-129.

Duffield, Mark [2010]. The Development-Security Nexus in Historical Perspective: Governing the World of Peoples. In. Sörensen, Jens Stilhoff (ed.). Challenging the Aid Paradigm. Western Currents and Asian Alternatives, Rethinking International Development Series. London: Palgrave Macmillan, s. 25-46.

Duffield, Mark - Hewitt, Vernon [2009a]. Introduction. In. Duffield, Mark - Hewitt, Vernon (ed.). Empire, Development and Colonialism. The Past in the Present. Woodbridge: James Currey, s. 1-15.

Duffield, Mark - Hewitt, Vernon, ed. [2009b]. Empire, Development and Colonialism. The Past in the Present. Woodbridge - Rochester: James Currey.

Dufour, Françoise [2014]. The Notion of „Development“ in French Colonial Discourses: Changes in Discursive Practices and Their Social Implications. In. Hodge, Joseph Morgan - Hödl, Gerald - Kopf, Martina (ed.). Developing Africa. Concepts and Practices in Twentieth Century Colonialism. Manchester: Manchester University Press, s. 322-340.

Easterly, William [2002]. The cartel of good intentions: The problem of bureaucracy in foreign aid. The Journal of Policy Reform 5 (4): 223-250.

Eckert, Andreas [2004]. Regulating the Social: Social Security, Social Welfare and the State in Late Colonial Tanzania. The Journal of African History 45 (3): 467-489.

Escobar, Arturo [1995]. Encountering Development. The Making and Unmaking of the Third World. Princeton: Princeton University Press.

Esteva, Gustavo [1992]. Development. In. Sachs, Wolfgang (ed.). The Development Dictionary. London New Jersey: Zed Books, s. 6-25.

Havinden, Michael A. - Meredith, Davided [1993]. Colonialism and Development: Britain and its Tropical Colonies, 1850-1960. London - New York: Routledge.

Helleiner, Eric [2014]. Forgotten Foundations of Bretton Woods: International Development and the Making of the Postwar Order. Ithaca, NY: Cornell University Press.

Hewitt, Vernon [2006]. A Cautionary Tale: Colonial and post-colonial conceptions of good government and democratisation in Africa. Commonwealth and Comparative Politics 44 (1): 41-61.

Hodge, Joseph Morgan [2007]. Triumph of the Expert. Agrarian Doctrines of Development and the Legacies of British Colonialism. Athens: Ohio University Press.

Hodge, Joseph M. [2010]. British Colonial Expertise, Post-Colonial Careering and the Early History of International Development. Journal of Modern European History 8 (1): 24-46.

Hodge, Joseph Morgan [2016a]. Writing the History of Development (Part 1: The First Wave). Humanity: An International Journal of Human Rights, Humanitarianism, and Development 6 (3): 429-463.

Hodge, Joseph Morgan [2016b]. Writing the History of Development (Part 2: Longer, Deeper, Wider). Humanity: An International Journal of Human Rights, Humanitarianism, and Development 7 (1): 125-174.

Hodge, Joseph Morgan - Hödl, Gerald [2014]. Introduction. In. Hodge, Joseph Morgan - Hödl, Gerald - Kopf, Martina (ed.). Developing Africa. Concepts and Practices in Twentieth Century Colonialism. Manchester: Manchester University Press, s. 1-34.

Hodge, Joseph Morgan - Hödl, Gerald - Kopf, Martinaed [2014]. Developing Africa. Concepts and practices in twentieth-century colonialism. Manchester: Manchester University Press.

Hunter, Emma [2014]. A history of maendeleo: the concept of „development“ in Tanganyika's late colonial public sphere. In. Hodge, Joseph Morgan - Hödl, Gerald - Kopf, Martina (ed.). Developing Africa. 
Concepts and Practices in Twentieth Century Colonialism. Manchester: Manchester University Press, s. $87-107$.

Jansen, Jan C. - Osterhammel, Jürgen [2017]. Decolonization: A Short History. Princeton: Princeton University Press.

Jenkins, Rob [2006]. Where development meets history. Commonwealth \& Comparative Politics 44 (1): 2-15.

Kelemen, Paul [2009]. „Individualism Is, Indeed, Running Riot“: Components of the Social Democratic Model of Development. In. Duffield, Mark - Hewitt, Vernon (ed.). Empire, Development and Colonialism. The Past in the Present. Woodbridge: James Currey, s. 188-202.

Koponen, Juhani [2014]. From dead end to new lease of life: development in South-Eastern Tanganyika from the late 1930 to the 1950s. In. Hodge, Joseph Morgan - Hödl, Gerald - Kopf, Martina (ed.). Developing Africa. Concepts and Practices in Twentieth Century Colonialism. Manchester: Manchester University Press, s. 37-62.

Kothari, Uma [2005]. From colonial administration to development studies: a post-colonial critique opf the history of development studies. In. Kothari, Uma (ed.). A Radical History of Development Studies. Individuals, Institutions and Ideologies. London - New York: Zed Books, s. 46-66.

Kothari, Smitu - Harcourt, Wendy [2004]. Introduction: The violence of development. Development 47 (1): $3-7$.

Latouche, Serge [1988]. Contribution à l'histoire du concept de développement. In. Coquery-Vidrovitchet, Catherine (ed.). Pour une histoire du développement. États, sociétés, développement. Paris: L'Harmattan, s. 41-60.

Leppenies, Philipp H. [2009]. Lernen vom Besserwisser: Wissenstransfer in der „Entwicklungshilfe“ aus historischer Perspektive. In. Büschel, Hubertus - Speich, Daniel (ed.). Entwicklungswelten. Globalgeschichte der Entwicklungszusammenarbeit. Frankfurt am Main: Campus, s. 33-59.

Low, D. A. - Lonsdale, John M. [1976]. Introduction: Towards the New Order 1945-1963. In. Low, D. A. Smith, Alison (ed.). History of East Africa, vol. 3. Oxford: Oxford University Press, s. 1-64.

Manji, Firoze - O'Coill, Carl [2002]. The missionary position: NGOs and development in Africa. International Affairs 78 (3): 567-583.

Merefield, Matthew [2009]. The Exceptional Inclusion of „Savages“ and „Barbarians“. The Colonial Liberal Bio-politics of Mobility and Development. In. Duffield, Mark - Hewitt, Vernon (ed.). Empire, Development and Colonialism. The Past in the Present. Woodbridge: James Currey, s. 16-29.

Nandy, Ashis [1995]. Development and Violence. Trier: Zentrum für europäische Studien.

Osterhammel, Jurgen [2005]. Colonialism: A Theoretical Overview. Princeton: Markus Wiener Pub.

Rahnema, Majid [1997]. Introduction. In. Rahnema, Majid - Bawtree, Victoria (ed.). The Post-Development Reader. London - New Jersey: Zed Books, s. ix-xix.

Rist, Gilbert [2008]. The History of Development: From Western Origins to Global Faith. London - New York: Zed Books.

Rizzo, Matteo [2006]. What Was Left of the Groundnut Scheme? Development Disaster and Labour Market in Southern Tanganyika 1946-1952. Journal of Agrarian Change 6 (2): 205-238.

Sachs, Wolfgang [1992]. Introduction. In. Sachs, Wolfgang (ed.). The Development Dictionary. London New Jersey: Zed Books, s. 1-5.

Scott, David [1995]. Colonial Governmentality. Social Text (43): 191-220.

Sheldon, Richard [2009]. Development, Poverty \& Famines. The Case of British Empire. In. Duffield, Mark - Hewitt, Vernon (ed.). Empire, Development and Colonialism. The Past in the Present. Woodbridge: James Currey, s. 74-87.

Schicho, Walter [2014a]. „Keystone of progres“" and mise en valeur d'ensemble: British and French colonial discourses on education for development in the interwar period. In. Hodge, Joseph Morgan - Hödl, Gerald - Kopf, Martina (ed.). Developing Africa. Concepts and Practices in Twentieth Century Colonialism. Manchester: Manchester University Press, s. 222-250.

Schicho, Walter [2014b]. Wirtschaftliche Inwertsetzung - la mise en valeur - und soziale Entwicklung. Der Entwicklungsdiskurs der kolonialen Verwaltung von Französisch Westafrika (AOF) zwischen 1920 und 1960. Stichproben. Wiener Zeitschrift für Afrikanstudien 14 (26): 49-105.

Schneider, Leander [2006]. Colonial Legacies and Postcolonial Authoritarianism in Tanzania: Connects and Disconnects. African Studies Review 49 (1): 93-118. 
Schlauß, David [2014]. Koloniale Entwicklungskonzepte im Uganda der 1930er Jahre: Frühe Anzeichen des modernen Entwicklungsstaats. Stichproben. Wiener Zeitschrift für Afrikanstudien 14 (26): 139-166.

Schlauß, David - Schicho, Walter [2014]. Kolonialismus und Entwicklung. Stichproben. Wiener Zeitschrift für Afrikanstudien 14 (26): 1-17.

Toye, John - Toye, Richard [2006]. How the UN moved from full employment to economic development. Commonwealth \& Comparative Politics 44 (1): 16-40.

Unger, Corinna [2010]. Histories of Development and Modernization: Findings, Reflections, Future Research. H-Soz-Kult. Kommunikation und Fachinformation für die Geschichtswissenschaften, 9. 12. 2010. Dostupné z: <http://www.hsozkult.de/literaturereview/id/forschungsberichte-1130>.

Usuanlele, Uyilawa [2014]. Development and education in British colonial Nigeria, 1940-55. In. Hodge, Joseph Morgan - Hödl, Gerald - Kopf, Martina (ed.). Developing Africa. Concepts and Practices in Twentieth Century Colonialism. Manchester: Manchester University Press, s. 251-269.

van Beusekom, Monica M. [2000]. Disjunctures in theory and practice: Making sense of change in agricultural development at the office du niger, 1920-60. The Journal of African History 41 (1): 79-99.

van Beusekom, Monica M. - Hodgson, Dorothy L. [2000]. Lessons Learned? Development Experiences in the Late Colonial Period. The Journal of African History 41 (1): 29-33.

Williams, David - Young, Tom [2009]. The International Politics of Social Transformation. Trusteeship and Intervention in Historical Perspective. In. Duffield, Mark - Hewitt, Vernon (ed.). Empire, Development and Colonialism. The Past in the Present. Woodbridge: James Currey, s. 102-115.

Wolton, S. [2000]. Lord Hailey, the Colonial Office and Politics of Race and Empire in the Second World War: The Loss of White Prestige. Basingstoke - New York: Palgrave Macmillan in association with St. Anthony's College.

Ziai, Aram [2006]. Zwischen Global Governance und Post-Development: Entwicklungspolitik aus diskursanalytischer Perspektive. Münster: Westfälisches Dampfboot.

Ziai, Aram [2016]. Development Discourse and Global History: From Colonialism to the Sustainable Development Goals. Oxon - New York: Routledge.

Tomáš Profant $\left({ }^{*} 1983\right)$ získal doktorát z politológie na Univerzite v Kasseli. Je výskumným pracovníkom na Ústave medzinárodných vztahov v Prahe a ako odborný asistent pôsobí na Fakulte sociálnych a ekonomických vied Univerzity Komenského v Bratislave. Medzi jeho odborné záujmy patrí medzinárodná politická ekonómia, politická ekológia, rozvojová spolupráca a postkoloniálna teória. Nedávno mu vyšla kniha New Donors on the Postcolonial Crossroads: Eastern Europe and Western Aid. 